[Regular Paper]

\title{
Effect of Addition Method of Phosphorus on Alumina-supported NiMoP Catalysts - Hydrodesulfurization of 4,6-Dimethyldibenzothiophene and Characterization Using MAS NMR-
}

\author{
Hideki Godo $^{\dagger 1) *}$, Kazuhiko HaGIWARA ${ }^{\dagger 1)}$, Takayuki OsaKI ${ }^{\dagger 1)}$, \\ Takashi FUJIKAWA $^{\dagger 1)}$, and Eika W. QIAN ${ }^{\dagger 2)}$ \\ ${ }^{\dagger 1}$ Research \& Development Center, Cosmo Oil Co., Ltd., 1134-2 Gongendo, Satte, Saitama 340-0193, JAPAN \\ †2) Dept. of Chemical Engineering, Tokyo University of Agriculture \& Technology, \\ 2-24-16 Naka-machi, Koganei, Tokyo 184-8588, JAPAN
}

(Received July 3, 2003)

\begin{abstract}
A series of Ni-Mo- $\mathrm{P} / \mathrm{Al}_{2} \mathrm{O}_{3}$ catalysts with phosphorus added by different methods were prepared. The hydrodesulfurization of 4,6-dimethyldibenzothiophene (4,6-DMDBT) was carried out using the catalysts. The catalysts were also characterized using magic angle spinning nuclear magnetic resonance (MAS NMR).

The hydrodesulfurization activities of phosphorized catalysts were changed from that of $\mathrm{NiMo} / \mathrm{Al}_{2} \mathrm{O}_{3}$ catalyst. Furthermore, the method for phosphorus addition affected their hydrodesulfurization activities. However, the activation energy and product selectivity for the hydrodesulfurization of 4,6-DMDBT were almost the same for all catalysts. It was indicated that the phosphorus content and the addition method did not change the mechanism of hydrodesulfurization of 4,6-DMDBT.

MAS NMR showed that the phosphorus addition method affected the dispersion of phosphorus on alumina. Catalyst with higher dispersion of phosphorus on alumina showed higher activity for hydrodesulfurization. Phosphorus addition may affect the structure of the molybdenum cluster and the degree of sulfidation of active metal.
\end{abstract}

\section{Keywords}

Nickel molybdenum catalyst, Phosphorus addition, Hydrodesulfurization, Dimethyldibenzothiophene,

Magic angle spinning NMR, Phosphorus dispersion

\section{1. 緒言}

近年，大都市圈を中心に自動車排気ガスによる大気污染が深 刻な問題となっている。これを解決するため，燃料油に対する より一層の低硫黄化が要望されている1)。

水素化脱硫触媒としてアルミナを担体とした CoMo 触媒, NiMo 触媒が処理油種に合わせて広く工業的に用いられている が，触媒活性の向上もしくは反応選択性（水素化反応／脱硫反 応比等), 水素消費量, 被毒抑制 (コーク被毒, メ夕ル被毒等) 等を制御することを目的に，Mo および $\mathrm{Ni}(\mathrm{Co})$ のほか，第 3 成 分を添加した触媒の研究が多く行われている2) 14)。その中で $\mathrm{P}$

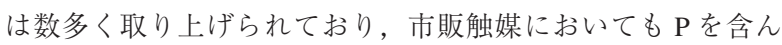
だ触媒は多数存在する。 $\mathrm{P}$ 添加は原料油中のへテロ原子（ $\mathrm{S}$, N）除去と水素化反応の選択性向上に有用であると報告されて (る) (10)。この効果についていくつかの提案がされている。 Gishti ら ${ }^{11)}$ は，P を添加することによりアルミナ上のルイス酸 点を修飾すると報告している。またZeuthen ら ${ }^{12)}$ は，Pの添加

* To whom correspondence should be addressed.

* E-mail: hideki_godo@cosmo-oil.co.jp
はアルミナと Mo の相互作用を弱めると報告している。さらに Prins ら ${ }^{14)}$ は，P を添加することで担体上に打ける活性金属の 分散性が向上すると報告している。このようなことから水素化 脱硫触媒における $\mathrm{P}$ 添加はアルミナの酸性質を修飾すること でアルミナと活性金属の相互作用を弱め，活性金属を高分散さ せていると推察できるが，直接的な証拠は得られていない。ま た，これらの報告例は CoMo を基準とした $\mathrm{P}$ 添加触媒につい て検討した場合が多く，水素化脱硫反応においてはベンゾチオ フェン（BT）やジベンゾチオフェン（DBT）を典型的な硫黄 化合物として扱った場合が多い。さらに，P の局所構造を解明 するために固体 NMR を用いた解析が実施されているが，Pの 添加量から検討した報告がほとんどである。一方, NiMo 触媒 を基準とした P の添加効果を難脱硫性化合物である 4,6-ジメチ ルジベンゾチオフェン（4,6-DMDBT） の水素化脱硫反応から 検討した報告は少なく, 特にP の添加方法が触媒活性および 触媒構造に及ぼす影響について未だ明らかになっていない。

そこで本研究では，これらを明確にするために，アルミナを 担体とした P 添加方法の異なる $\mathrm{NiMoP}$ 触媒を調製し，4,6DMDBT の水素化脱硫反応を行った。そして, 脱硫活性抒よび 
反応機構において $\mathrm{P}$ 添加方法の影響を検討した。さらに，固 体 MAS (magic angle spinning) NMR (nuclear magnetic resonance）を用いて, P および $\mathrm{Al}$ の微視的な配位状態を分析し, $\mathrm{P}$ 添加および $\mathrm{P}$ 添加方法が触媒の構造に及ぼす影響について検 討した。

\section{2. 実験}

\section{1. 触媒調製}

$\mathrm{NiMo} / \mathrm{Al}_{2} \mathrm{O}_{3}$ 触媒（NiO: 4 mass\%, $\mathrm{MoO}_{3}: 16$ mass\%）抒よび $\mathrm{P}$ 添加方法の異なる 4 種の $\mathrm{NiMoP} / \mathrm{Al}_{2} \mathrm{O}_{3}$ 触媒（NiO: 4 mass\%, $\mathrm{MoO}_{3}: 16$ mass\%， $\mathrm{P}_{2} \mathrm{O}_{5}: 3$ mass\%) を含浸法にて調製した。担 体には $\gamma-\mathrm{Al}_{2} \mathrm{O}_{3}$ (形状: 四葉型ペレット，比表面積: $318 \mathrm{~m}^{2} / \mathrm{g}$ ) を，担持金属である Mo， Ni そして P はモリブデン酸アンモニ ウム, 硝酸ニッケル 6 水和物, リン酸の試薬（何れも和光純薬 工業(株)製）を使用した。以下，各触媒の調製手順を示す。

(1) $\mathrm{Mo}-\mathrm{Ni} / \mathrm{Al}_{2} \mathrm{O}_{3}$ (Cat.A)

$\gamma-\mathrm{Al}_{2} \mathrm{O}_{3}$ に $\mathrm{Mo}$ 水溶液を含浸し, $500^{\circ} \mathrm{C}$ で焼成を行い, $\mathrm{Mo} /$ $\mathrm{Al}_{2} \mathrm{O}_{3}$ を得た。次に, この $\mathrm{Mo} / \mathrm{Al}_{2} \mathrm{O}_{3}$ に $\mathrm{Ni}$ 水溶液を含浸し, $500^{\circ} \mathrm{C}$ で焼成を行い，Mo- $\mathrm{Ni} / \mathrm{Al}_{2} \mathrm{O}_{3}$ を得た。

(2) $\mathrm{NiMoP} / \mathrm{Al}_{2} \mathrm{O}_{3}$ (Cat.B)

イオン交換水に所定量の $\mathrm{Ni}$ 試薬，Mo 試薬および $\mathrm{P}$ 試薬を 同時に添加した後, $70^{\circ} \mathrm{C}$ でかくはんし， NiMoP 水溶液を得た。 この $\mathrm{NiMoP}$ 水溶液を $\gamma-\mathrm{Al}_{2} \mathrm{O}_{3}$ に含浸し, $500^{\circ} \mathrm{C}$ で焼成を行い, $\mathrm{NiMoP} / \mathrm{Al}_{2} \mathrm{O}_{3}$ を得た。

(3) $\mathrm{P}-\mathrm{Mo}-\mathrm{Ni} / \mathrm{Al}_{2} \mathrm{O}_{3}$ (Cat.C)

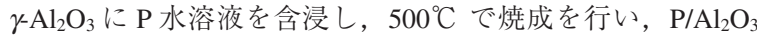

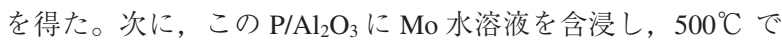
焼成を行い, $\mathrm{P}-\mathrm{Mo} / \mathrm{Al}_{2} \mathrm{O}_{3}$ を得た。さらに, この $\mathrm{P}-\mathrm{Mo} / \mathrm{Al}_{2} \mathrm{O}_{3}$ に $\mathrm{Ni}$ 水溶液を含浸し, $500^{\circ} \mathrm{C}$ で焼成を行い, $\mathrm{P}-\mathrm{Mo}-\mathrm{Ni} / \mathrm{Al}_{2} \mathrm{O}_{3}$ を得 た。

\section{(4) $\mathrm{Mo}-\mathrm{P}-\mathrm{Ni} / \mathrm{Al}_{2} \mathrm{O}_{3}$ (Cat.D)}

Cat.C と同様の手法を用い，1段目にMo を 2 段目に $\mathrm{P}$ をそ して 3 段目に $\mathrm{Ni}$ を含浸担持し, Mo-P-Ni/ $\mathrm{Al}_{2} \mathrm{O}_{3}$ を得た。

(5) $\mathrm{Mo}-\mathrm{Ni}-\mathrm{P} / \mathrm{Al}_{2} \mathrm{O}_{3}$ (Cat.E)

Cat.C と同様の手法を用い，1 段目にMo を 2 段目に Ni をそ して 3 段目に P を含浸担持し, Mo- $\mathrm{Ni}-\mathrm{P} / \mathrm{Al}_{2} \mathrm{O}_{3}$ を得た。

\section{2. 触媒分析}

調製した触媒の金属担持量は高周波プラズマ発光金属分析計 （(株）島津製作所製，ICPS-2200）を用いて分析した。また，触 媒の比表面積について表面積測定装置（日本ベル(株)製，ベル ソープ 28）を用い，窒素吸着法にて測定し，BET 法にて算出 した。

\section{3. 水素化脱硫反応}

反応には固定床高圧流通式反応装置を使用した。反応を行う 前に, 大気圧, $350^{\circ} \mathrm{C}$ の条件下で 1 時間, $\mathrm{H}_{2} \mathrm{~S}(5 \mathrm{vol} \%) / \mathrm{H}_{2}$ ガス を流通させ，触媒を硫化した。

反応は 0.4 mass\% 4,6-DMDBT (Aldrich Chem. Co. 製) /デカ ヒドロナフタレン (関東化学(株)製) 溶液を原料油として用い, 反応温度: $230 \sim 270^{\circ} \mathrm{C}$, 圧力: $4.9 \mathrm{MPa}$, 液空間速度 (WHSV): $10 \mathrm{~h}^{-1}$, 水素/原料比: $700 \mathrm{~m}^{3}$ (normal)/ $\mathrm{k} l$ の条件下で行った。反 応生成物は各温度に達してから 4 時間後, 気液分離管より採取 し，分析を行った。
Table 1 Composition and Surface Area of Catalysts

\begin{tabular}{ccccc}
\hline Catalyst & $\begin{array}{c}\mathrm{NiO} \\
{[\text { mass \%] }}\end{array}$ & $\begin{array}{c}\mathrm{MoO}_{3} \\
{[\mathrm{mass} \%]}\end{array}$ & $\begin{array}{c}\mathrm{P}_{2} \mathrm{O}_{5} \\
{[\mathrm{mass} \%]}\end{array}$ & $\begin{array}{c}\text { Surface area } \\
{\left[\mathrm{m}^{2} / \mathrm{g}\right]}\end{array}$ \\
\hline Cat.A & 4.1 & 16.5 & 0 & 268 \\
Cat.B & 4.1 & 16.5 & 3.0 & 237 \\
Cat.C & 4.1 & 16.5 & 3.0 & 226 \\
Cat.D & 3.9 & 16.5 & 2.7 & 229 \\
Cat.E & 3.9 & 16.5 & 2.7 & 236 \\
\hline
\end{tabular}

\section{4. 生成物分析}

反応生成物中の硫黄濃度を $\mathrm{X}$ 線硫黄分析計 (ニューリー(株) 製，RX-610SA）で測定し，4,6-DMDBT の脱硫率 (HDS) 拈よ び各触媒の脱硫活性（擬一次反応速度定数, $k_{\mathrm{HDS}}$ ) をそれぞれ Eqs. (1)，(2)を用いて算出した。

$$
\begin{aligned}
& H D S=\left(1-S_{\text {product }} / S_{\text {feed }}\right) \times 100 \\
& k=\ln \left(S_{\text {feed }} / S_{\text {product }}\right) \times W H S V \\
& S_{\text {feed: }} \text { 原料に含まれる硫黄濃度 } \\
& S_{\text {product: }} \text { 生成物に含まれる硫黄濃度 }
\end{aligned}
$$

さらに，ガスクロマトグラフィー／原子発光検出器 (GCAED, GC (gas chromatography): Hewlett Packard 5890, AED (atomic emission detector): Hewlett Packard 5921A) を用いて生 成物の同定㧍よび定量を行い, 生成物の選択率を Eq. (3)によ り算出した。

$$
\text { 選択率 }=(\text { 各生成物濃度 /全生成物濃度 }) \times 100
$$

\section{5. 固体 MAS NMR}

測定には日本電子(株) 製 JNM-CMX-400 を用い, シングルパ ルスにより十分水和した試料を測定した。 ${ }^{31} \mathrm{P}-\mathrm{MAS}$ NMR の測 定条件はパルス幅 $\pi / 4$, 繰り返し時間 $15 \mathrm{~s}$, MAS 速度 $12 \mathrm{kHz}$, 積算回数 600 とした。 ${ }^{31} \mathrm{P}$ の化学シフトの 2 次基準物質として $\left(\mathrm{NH}_{4}\right)_{2} \mathrm{HPO}_{4}$ を用い, そのピーク位置を $\mathrm{H}_{3} \mathrm{PO}_{4}$ 水溶液基準で 1.3 $\mathrm{ppm}$ とした。一方, ${ }^{27} \mathrm{Al}-\mathrm{MAS} \mathrm{NMR} の$ 測定条件はパルス幅 $\pi / 12$, 繰返し時間 $2 \mathrm{~s}$, MAS 速度 $12 \mathrm{kHz}$, 積算回数 400 とした。 ${ }^{27} \mathrm{Al}$ の化学シフトの基準には, $1 \mathrm{~mol} / /$ の $\mathrm{Al}\left(\mathrm{NO}_{3}\right)_{3}$ 水溶液を用 いた。

\section{3. 結果および考察}

\section{1. 触媒分析}

各触媒の金属担持量および比表面積を Table 1 に示す。 Cat.A に扔ける P 以外, 全ての触媒において金属担持量はほぼ 同じであることを確認した。また， $\mathrm{P}$ 無添加触媒（Cat.A）と 比較すると, 添加方法に関わらず $\mathrm{P}_{2} \mathrm{O}_{5}$ を約 3 mass \% 担持する ことで触媒の比表面積は約 $30 \mathrm{~m}^{2} / \mathrm{g}$ 減少することがわかった。

\section{2. 脱硫活性}

各触媒による 4,6-DMDBT の水素化脱硫反応結果を Table 2 に示す。P無添加触媒（Cat.A）と比較し，P を活性金属（Mo, $\mathrm{Ni}$ ) より後に添加した触媒（Cat.D, Cat.E）の脱硫活性は低下 した。一方, $\mathrm{P}$ を活性金属より前に添加した触媒（Cat.C）は P 無添加触媒よりも高脱硫活性を示した。さらに, P を活性金属 と同時に担持した触媒 (Cat.B) の脱硫活性は最も高く, $\mathrm{P}$ 無 添加触媒よりも 1.2 倍以上の脱硫活性を示した。すなわち, 脱 硫活性は Cat.B > Cat.C > Cat.A > Cat.D > Cat.E の順であり，こ 
Table 2 Hydrodesulfurization of 4,6-DMDBT

\begin{tabular}{cccr}
\hline Catalyst & Temperature $\left[{ }^{\circ} \mathrm{C}\right]$ & $H D S[\%]$ & $k_{\mathrm{HDS}}\left[\mathrm{h}^{-1}\right]$ \\
\hline Cat.A & 230 & 19.7 & 2.2 \\
& 250 & 51.0 & 7.0 \\
& 270 & 78.8 & 16.2 \\
Cat.B & 230 & 26.0 & 2.7 \\
& 250 & 58.0 & 8.5 \\
& 270 & 87.5 & 21.4 \\
Cat.C & 230 & 23.5 & 2.5 \\
& 250 & 55.3 & 8.1 \\
& 270 & 83.2 & 18.3 \\
Cat.D & 230 & 21.0 & 2.3 \\
& 250 & 47.0 & 6.3 \\
& 270 & 76.1 & 15.1 \\
Cat.E & 230 & 19.7 & 2.1 \\
& 250 & 41.0 & 5.4 \\
& 270 & 69.2 & 12.8 \\
\hline
\end{tabular}

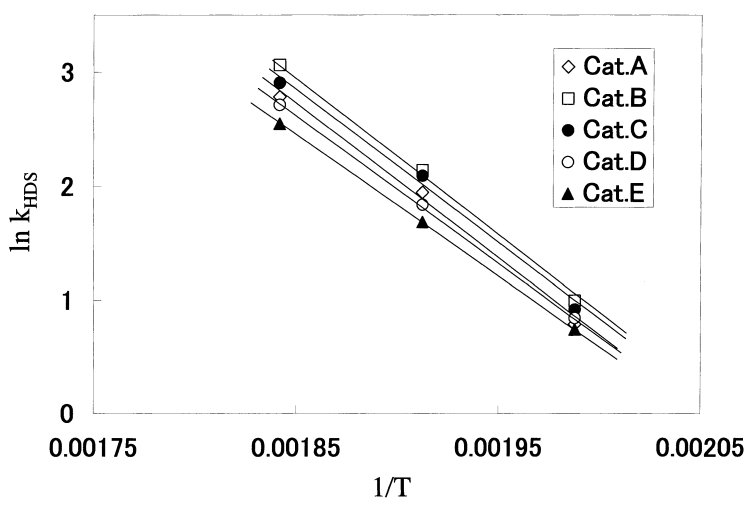

Fig. 1 Arrhenius Plots of $k_{\mathrm{HDS}}$

のことから水素化脱硫反応に扔いて NiMo 触媒における $\mathrm{P}$ 添加 は添加方法により正負両方の効果を有することがわかった。

Table 2 の值を用い, アレニウスプロットしたものを Fig. 1 に示す。直線の傾きから各触媒での 4,6-DMDBT の水素化脱硫 反応に㧍ける見かけの活性化エネルギーを算出した。結果を Table 3 に示す。何れの触媒に打いても, 活性化エネルギーは $130 \pm 8 \mathrm{~kJ} / \mathrm{mol}(31 \pm 2 \mathrm{kcal} / \mathrm{mol})$ であった。Zhang ら $\left.{ }^{15}\right)$ は, CoMo/ $\mathrm{Al}_{2} \mathrm{O}_{3}$ 触媒を用いた際の活性化エネルギーを $33 \pm 2 \mathrm{kcal} / \mathrm{mol}$ と 報告しており，本研究においてもほぼ同等の值を示した。

本研究で評価した触媒間において活性化エネルギーは大きく 変化しなかった。このことから NiMo 触媒において 4,6DMDBT の水素化脱硫反応機構は $\mathrm{P}$ 添加の有無, さらに $\mathrm{P}$ 添加 方法に影響を受けないと推測される。

\section{3. 反応機構解析}

$\mathrm{P}$ 添加および $\mathrm{P}$ 添加方法が脱硫活性に影響を及ぼした要因を 反応機構から検討するため, GC-AED を用い生成物の分析を 行った。4,6-DMDBT の水素化脱硫反応では Fig. 2 に示すよう に, 硫黄が直接脱硫される 3,3 '-ジメチルビフェニル（3,3'DMBP), 芳香環の片方が水素化された後, 脱硫される 3,3 '-ジ メチルシクロヘキシルベンゼン (3,3'-DMCHB), そして $3,3^{\prime}$ -
Table 3 Activation Energy

\begin{tabular}{cc}
\hline Catalyst & Activation energy $[\mathrm{kJ} / \mathrm{mol}]$ \\
\hline Cat.A & 133 \\
Cat.B & 137 \\
Cat.C & 132 \\
Cat.D & 125 \\
Cat.E & 122 \\
\hline
\end{tabular}

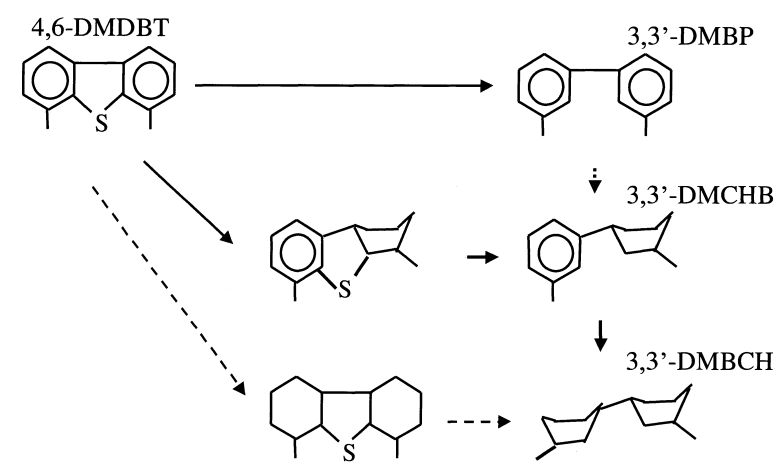

Fig. 2 Hydrodesulfurization Pathway for 4,6-DMDBT

DMCHB の芳香環がさらに水素化される 3,3 ’-ジメチルビシク ロヘキシル（3,3'-DMBCH）が生成するルートが考えられる。

Figs. 3〜7 に各触媒を用いた場合の各生成物の選択率に及ぼ す反応温度の影響を示す。本研究に扮いて主生成物は $3,3^{\prime}-$ DMCHB であり, そのほかに3,3’-DMBP および 3,3'-DMBCH の生成が確認できた。Mochida ${ }^{16), 17)}$ はメチル基を有さない DBT の水素化脱硫反応に拈いては直接, C-S 結合が解離し, BP が生成する直接脱硫ルートが支配的だが，メチル基を有す る 4,6-DMDBT の水素化脱硫反応においては一旦, 芳香環が水 素化された後, C-S 結合が解離する間接脱硫ルートが支配的で あると報告しており，本研究においてもこの結果を支持した。 また, 何れの触媒を用いても, 各生成物の選択率は反応温度に 依存することがわかった。反応温度の上昇に伴い，4,6DMDBT 中の C-S 結合の解離が進行することで 3,3'-DMBP は わずかながら増加し，また生成した $3,3^{\prime}-\mathrm{DMCHB}$ のさらなる 水素化が進行することにより 3,3'-DMBCH は増加し, その結 果 3,3'-DMCHB の選択率は減少したものと思われる。

一方, 各生成物の選択率は, 活性化エネルギーと同様に, 触 媒による差がほとんど認められなかった。したがって，このこ とからも NiMo 触媒において 4,6-DMDBT の水素化脱硫反応機 構は $\mathrm{P}$ 添加の有無, さらに $\mathrm{P}$ 添加方法に影響を受けないと推 測される。

Kabe ら ${ }^{1)} は ， 4,6-D M D B T$ の脱硫反応を促進させるには，水 素化活性を向上させることで芳香環を水素化し, メチル基の立 体障害を緩和することが有用であると報告している。しかし， 本研究において各生成物の選択率は触媒による差がほとんどな かったことから NiMo 触媒における $\mathrm{P}$ 添加, さらにP 添加方法 は活性点の構造を変化させ, 間接脱硫ルートを促進させること で脱硫活性を向上させるのではなく, 活性点の数を増加させる 


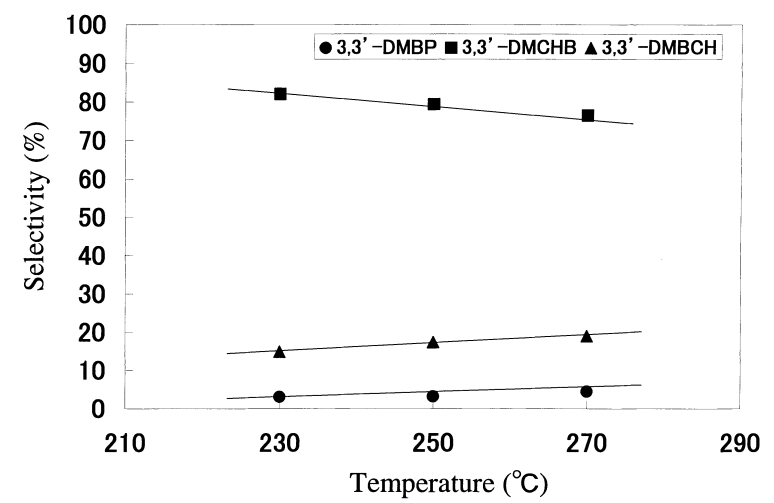

Fig. 3 Effect of Temperature on Selectivity in Hydrodesulfurization of 4,6-DMDBT for Cat.A

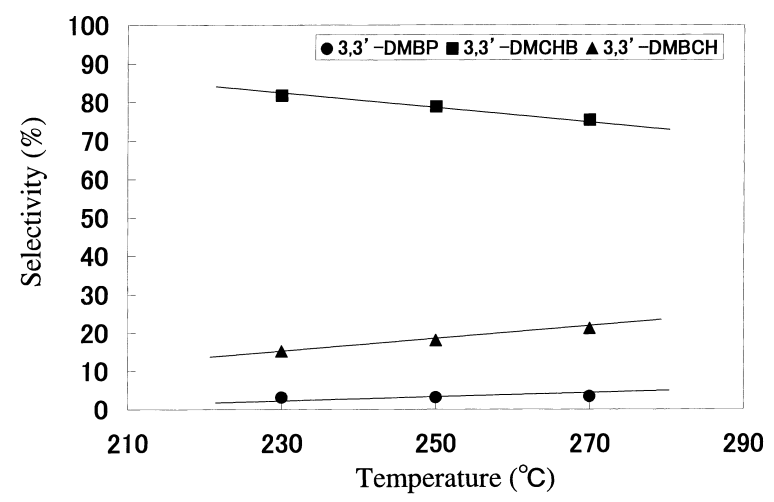

Fig. 4 Effect of Temperature on Selectivity in Hydrodesulfurization of 4,6-DMDBT for Cat.B

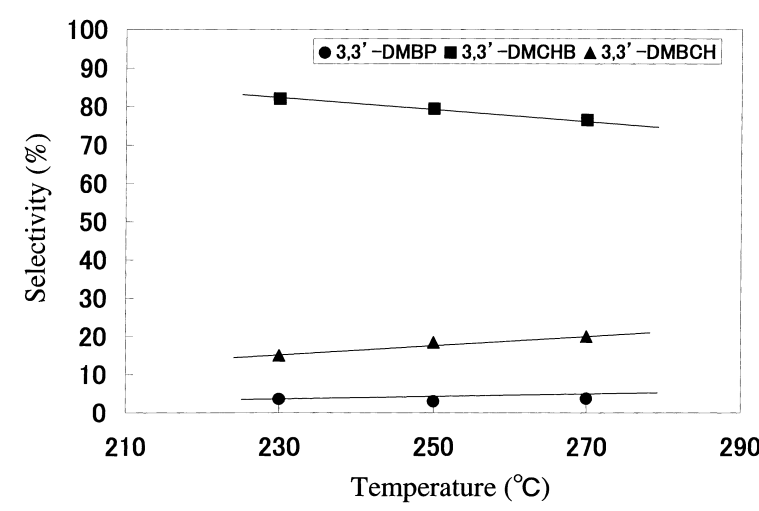

Fig. 5 Effect of Temperature on Selectivity in Hydrodesulfurization of 4,6-DMDBT for Cat.C

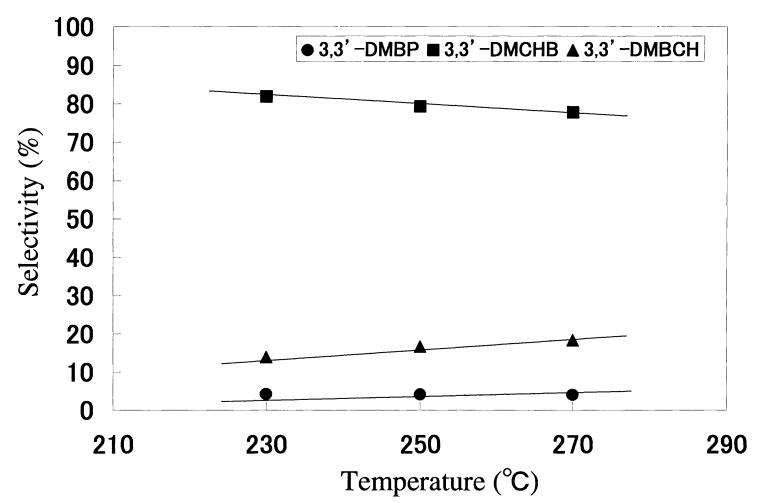

Fig. 6 Effect of Temperature on Selectivity in Hydrodesulfurization of 4,6-DMDBT for Cat.D

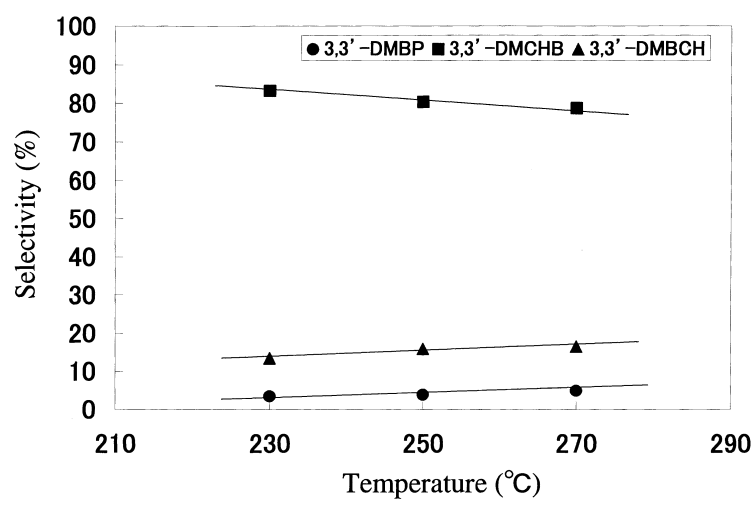

Fig. 7 Effect of Temperature on Selectivity in Hydrodesulfurization of 4,6-DMDBT for Cat.E

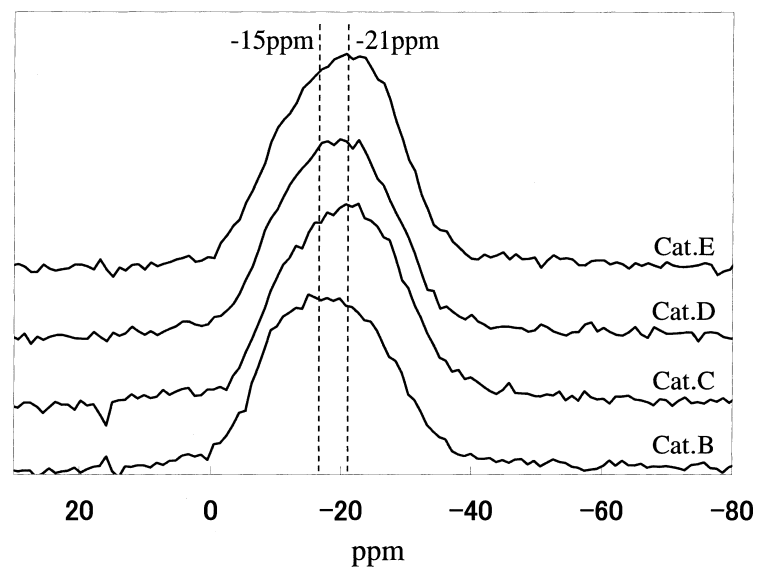

Fig. $8{ }^{31}$ P-MAS NMR Spectra of Catalysts with Added Phosphorus

\section{ことで脱硫活性を向上させると考えられる。}

\section{4. ${ }^{31}$ P-MAS NMR}

Fig. 8 に 添加触媒の ${ }^{31} \mathrm{P}-\mathrm{MAS}$ NMR スペクトルを示す。こ れらの触媒は全て常磁性物質である $\mathrm{Ni}$ を含むことから，測定 された $\mathrm{P}$ 酸塩に帰属するピークは $\mathrm{Ni}$ の常磁性効果により著し
く広幅化した ${ }^{18)}$ 。このように広幅化したピークの位置（化学シ フト）を詳細に解析することは困難であるものの, P を活性金 属と同時に添加した触媒 (Cat.B) ではピークトップの化学シ フトが約 $-15 \mathrm{ppm}$ だったのに対し，Pを逐次で添加した触媒は 


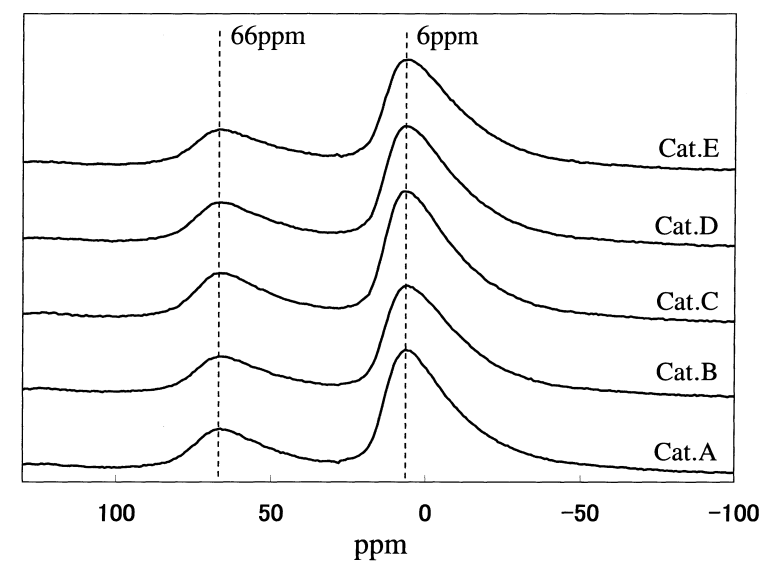

Fig. $9{ }^{27} \mathrm{Al}-\mathrm{MAS}$ NMR Spectra of Catalysts

約 $-21 \mathrm{ppm}$ となり, 約 $-6 \mathrm{ppm}$ シフトした。既往の研究によれ ば $\mathrm{P}$ 酸塩が monomeric から polymeric になる，すなわち $\mathrm{P}$ を含 むアニオンクラスターのサイズが大きくなるに従い, ${ }^{31} \mathrm{P}$ の化 学シフトが減少する（高磁場側にシフトする）ことが報告され ている19,20)。これらに基づけば，Cat.B 上での $\mathrm{P}$ を含むクラス ターのサイズは他の触媒に比べて小さいことが示唆された。す なわち，アルミナ担体上での P の分散性が高いことを示して いる。このことから $\mathrm{P}$ を活性金属と同時に添加した触媒は $\mathrm{P}$ を逐次で添加した触媒と比べ，アルミナ担体上でのP の分散 性が高いことが推測された。

逐次で $\mathrm{P}$ を添加した触媒間において顕著な差はなかったた め正確な議論は難しいが，Pは Cat. B > Cat.C $\fallingdotseq$ Cat.D > Cat.E の 順でアルミナ担体上に高分散していると考えられる。一方, 4,6-DMDBT の水素化脱硫反応に扔いて Cat.B > Cat.C > Cat.D > Cat.Eの順で高活性を示した。このことから P の分散性は脱硫 活性に何らかの影響を及ぼすと考えられる。Decanio ら ${ }^{19)}$ は NMR およびIR を用いた研究により，Mo触媒に扔いて適度に $\mathrm{P}$ を添加すると $\mathrm{P}$ はアルミナ担体上に monomeric な状態で存在 し，Mo を八面体構造に変換させることを見い出した。そして この八面体構造を有する Mo は硫化過程において積層化し, 脱 硫反応抢よび脱窒素反応に扔いて高活性な Ni-Mo-S 相を形成 することを提案している ${ }^{19)}$ 。ここで積層化した Mo 硫化物の硫 化度 (硫化割合) は単層の Mo 硫化物の硫化度と比較して高い と考えられている ${ }^{21)}$ 。よって本検討において, Cat.Bが反応機 構を変化させずに高脱硫活性を示したのは，P を活性金属と同 時に添加することで Pがアルミナ担体上に高分散化し，Mo を 八面体構造に変換させ, 硫化度が向上することで, 活性点が増 加したためと考えられる。

また， $\mathrm{P}$ とアルミナの複合酸化物である $\mathrm{AlPO}_{4}$ の $\mathrm{P}$ に帰属す る約 $-30 \mathrm{ppm}$ のピークは何れの触媒においても確認できなか った。したがって，本検討で調製した $\mathrm{P}$ 添加触媒には $\mathrm{AlPO}_{4}$ がほとんど存在しないことが推測された。

\section{5. ${ }^{27} \mathrm{Al}$-MAS NMR}

Fig. 9 に各触媒の ${ }^{27}$ Al-MAS NMR スペクトルを示す。一般 に $\gamma-\mathrm{Al}_{2} \mathrm{O}_{3}$ の ${ }^{27} \mathrm{Al}-\mathrm{MAS} \mathrm{NMR}$ では, 約 $6 \mathrm{ppm}$ に 6 配位 $\mathrm{Al}$ に州 属するピーク，約 $66 \mathrm{ppm}$ に 4 配位 $\mathrm{Al}$ に帰属するピークが現
れ22), $\mathrm{AlPO}_{4}$ に帰属するピークは約 $40 \mathrm{ppm}$ に現れる ${ }^{19)}$ 。本研究 で用いた試料では $\mathrm{P}$ 添加の有無や添加方法に関わらず，スペ クトルの形状はほぼ一致した。すなわち， $\gamma-\mathrm{Al}_{2} \mathrm{O}_{3}$ に含まれる 4 配位 $\mathrm{Al}$ および 6 配位 $\mathrm{A} 1$ に帰属するピークが現れたものの, $\mathrm{AlPO}_{4}$ に帰属するピークは現れなかった。この結果より, 担体 である $\gamma-\mathrm{Al}_{2} \mathrm{O}_{3}$ 中の $\mathrm{Al}$ のバルクでの配位状態は $\mathrm{P}$ 添加の有無 や添加方法によって変化しないことがわかった。

また, $\mathrm{AlPO}_{4}$ に帰属するピークが現れなかったのは，Pの添 加量が酸化物換算で約 3 mass \% と少なかったためと推測され る。すなわち, $\mathrm{AlPO}_{4}$ はスペクトルに現れるほど試料中に存在 しない。この結果は, 前述した ${ }^{31} \mathrm{P}-\mathrm{MAS}$ NMR スペクトル (Fig. 8) に㧍いて $\mathrm{AlPO}_{4}$ に帰属する $-30 \mathrm{ppm}$ 以下のピークが 明確に現れなかったことと一致した。

\section{4. 結 論}

アルミナを担体とした NiMo 触媒㧍よび $\mathrm{P}$ 添加方法の異なる 4 種の NiMoP 触媒を調製し, 4,6-DMDBT の水素化脱硫反応扮 よび固体 MAS NMR を用いた $\mathrm{P}, \mathrm{Al}$ の微視的状態分析を行っ た結果, 以下の知見が得られた。

（1）脱硫活性は Cat.B > Cat.C > Cat.A > Cat.D > Cat.E の順であ り, 水素化脱硫反応において NiMo 触媒における $\mathrm{P}$ 添加は添加 方法により正負両方の効果を有した。

（2）何れの触媒を用いた場合でも 4,6-DMDBT の水素化脱硫反 応における活性化エネルギーは $130 \pm 8 \mathrm{~kJ} / \mathrm{mol}$ であった。

（3）何れの触媒を用いた場合でも 4,6-DMDBT の水素化脱硫反 応に扔いて主生成物は 3,3'-DMCHB であり, 間接脱硫ルート が支配的であることが確認できた。そのほかに 3,3'-DMBP, 3,3'-DMBCH が生成し, 各生成物の選択率は反応温度に依存し, 触媒による差はなかった。

（4）活性化エネルギーおよび反応選択性は触媒による差が認め られなかったことから, NiMo 触媒における $\mathrm{P}$ 添加, さらに $\mathrm{P}$ 添加方法は 4,6-DMDBT の水素化脱硫反応機構に影響を及ぼさ ない, すなわち触媒上の活性点の構造は変化させないと考えら れる。

（5）MAS NMR の結果より， $\mathrm{Al}$ の配位状態は P 添加の有無, さらに $\mathrm{P}$ 添加方法に影響を受けないが, $\mathrm{P}$ 添加触媒において $\mathrm{P}$ 添加方法はアルミナ担体上での $\mathrm{P}$ の分散状態に影響を及ぼし た。 P は Cat. B > Cat. C $\fallingdotseq$ Cat.D > Cat.E の順で高分散していると 推測され, 脱硫活性の序列とほほ一致した。Pの分散性は活性 金属の硫化度を変化させ, 脱硫活性に影響を及ぼすと考えられ る。

（6）したがって， NiMo 触媒における P 添加は添加方法により 脱硫活性に影響を及ぼすが，これは活性点の構造を変化させる のでなく，活性金属の硫化度すなわち活性点の数を変化させる ことに起因すると考察した。

\section{References}

1) Kabe, T., Ishihara, A., Qian, W., "Hydrodesulfurization and Hydrodenitrogenation," Kodansha, Tokyo (1999).

2) Houalla, M., Delmon, B., Appl. Catal., 1, 285 (1981).

3) Saini, A. R., Johnson, B. G., Massoth, F. E., Appl. Catal., 40, 157 (1988).

4) Cui, J.-W., Massoth, F. E., Topsøe, N.-Y., J. Catal., 136, 361 
(1992).

5) Lycourghiotis, A., Vattis, D., React. Kinet. Catal. Lett., 21, 23 (1982).

6) Atanasova, P., Halachev, T., Uchytil, J., Kraus, M., Appl. Catal., 38, 235 (1988).

7) Morales, A., Ramirez De Agudelo, Hernandez, F., Appl. Catal., 41, 261 (1988).

8) Eijsbouts, S., Van Gestel, J. N. M., Van Veen, J. A. R., De Beer, V. H. J., Prins, R., J. Catal., 131, 412 (1991).

9) Poulet, O., Hubaut, R., Kasztelan, S., Grimblot, J., Bull. Soc. Chim. Belg., 100, 857 (1991)

10) Jian, M., Prins, R., Catal. Lett., 35, 193 (1995).

11) Gishti, K., Iannibello, A., Marengo, S., Morelli, G., Tittarelli, P., Appl. Catal., 12, 381 (1984).

12) Zeuthen, P., Blom, P., Muegge, B., Massoth, F. E., Appl. Catal., 68, 117 (1991).

13) Atanasova, P., Halachev, T., Appl. Catal., 48, 295 (1989).
14) Bouwens, S. M. A. M., Van Der Kraan, A. M., De Beer, V. H. J., Prins, R., J. Catal., 128, 559 (1991).

15) Zhang, Q., Ishihara, A., Kabe, T., Sekiyu Gakkaishi (J. Jpn. Petrol. Inst.), 39, (6), 410 (1996).

16) Whitehurst, D. D., Isoda, T., Mochida, I., Advances in Catalysis, 42, 345 (1998)

17) Isoda, T., Ma, K., Mochida, I., Sekiyu Gakkaishi (J. Jpn. Petrol. Inst.), 37, (4), 368 (1994).

18) Kraus, H., Prins, R., J. Catal., 170, 20 (1997).

19) Decanio, E. C., Edwards, J. C., Scalzo, T. R., Storm, D. A., Bruno, J. W., J. Catal., 132, 498 (1991).

20) Iwamoto, R., Fernandez, C., Amoureux, J. P., Grimblot, J., J. Phys. Chem. B, 102, 4342 (1998).

21) Topsøe, H., Clausen, B. S., Topsøe, N.-Y., Zeuthen, P., Stud. Surf. Sci. Catal., 53, 77 (1989).

22) Kurokawa, Y., Kobayashi, Y., Nakata, S., Heterogeneous Chemistry Reviews, 1, 309 (1994).

要旨

\title{
アルミナ担持 NiMoP 触媒における P 添加方法の影響
} 一4,6-ジメチルジベンゾチオフェンの水素化脱硫反応および固体 NMR による検討一

\author{
神戸 英樹 ${ }^{\dagger 1)}$, 萩原 和彦 ${ }^{\dagger 1)}$, 大崎 貴之 $^{\dagger 1)}$, 藤川 貴志 ${ }^{\dagger 1)}$, 銭 衛華 $^{\dagger 2)}$ \\ †1) コスモ石油(株) 中央研究所, 340-0193 埼玉県幸手市権現堂 1134-2 \\ †2) 東京農工大学工学部化学システム工学科, 184-8588 東京都小金井市中町 2-24-16
}

アルミナを担体とした NiMo 触媒掞よび P 添加方法の異なる 4 種の NiMoP 触媒を用いて，4,6-ジメチルジベンゾチオフェン (4,6-DMDBT) の水素化脱硫反応抢よび MAS NMR 解析を行 い，NiMoP 触媒における $\mathrm{P}$ 添加方法の影響を検討した。

脱硫活性において P 添加は添加方法により正負両方の効果 を有することがわかった。一方, 動力学的検討抢よび反応機構 解析の結果, 活性化エネルギーおよび生成物の選択性には P 添加の有無および添加方法による差がなかった。この結果は,
NiMo 触媒における P の添加㧍よび P の添加方法は 4,6-DMDBT の水素化脱硫反応機構に影響を及ほささないことを示唆してい る。また, MAS NMRを用いて触媒表面構造を解析した結果, $\mathrm{P}$ の添加方法はアルミナ担体上での $\mathrm{P}$ の分散状態に影響を及ほ すことがわかった。そして触媒上のP が高分散しているほど 触媒は高脱硫活性を示す傾向にあった。これは, Pの分散性が 担持された Mo クラスターの構造に影響を及ぼし, 硫化過程に 扔いて活性金属の硫化度に影響を及ぼすためと考えられる。 